\title{
Kayseri ilinde Halkın 112 Acil Yardım Hizmetleri Hakkında Bilgi, Düşünce ve Memnuniyet Düzeyleri
}

\section{Knowledge, Consideration and Satisfaction Level of People in Kayseri Province About The 112 Emergency Health Services}

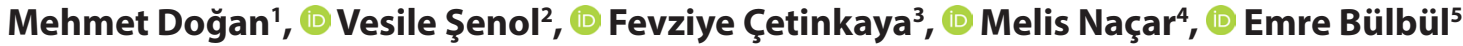 \\ 'Erciyes University Health Services Vocational School, Kayseri, Turkey \\ ${ }^{2}$ Kapadokya University High School of Health Sciences, Nevşehir, Turkey \\ ${ }^{3}$ Erciyes University Faculty of Medicine Department of Public Health, Kayseri, Turkey \\ ${ }^{4}$ Erciyes University Faculty of Medicine Department of Medical Education, Kayseri, Turkey \\ ${ }^{5}$ Kayseri City Hospital Department of Emergency Medicine, Kayseri, Turkey
}

Öz

Amaç: Sağlık hizmetlerinde en önemli kalite kriteri hasta memnuniyetidir. Hasta memnuniyetinin belirlenmesi hizmet kalitesinin artırılması ve hastaların beklentisi doğrultusunda daha nitelikli hizmet sunulması açısından önemlidir. Bu çalıs̆ma halkın 112 acil sağlık hizmetlerinin yapısı, işleyişi hakkındaki bilgi ve düşüncelerini, hizmetten memnuniyet düzeylerini belirlemek amacıyla yapılmıştır.

Gereç ve Yöntem: Kesitsel nitelikteki çalışma 2013 yılı mayıs ayında Kayseri'deki 18 acil yardım istasyonu arasından rastgele seçilen altı istasyondaki bölge halkından toplam 600 kişiye anket uygulanarak yapılmıştır.

Bulgular: Araştırma grubunun yaş ortalaması $35.25 \pm 11.38$, \%52,7'si kadın, \%67,0'ı evli, \%64,6'sı lise ve üzerinde eğitim almıştır. Grubun \%94,8'i 112 acil yardım cağrı numarasını bilmis, \%87,2'si yalnız acil durumlar için ambulans çağırdığını bildirmiştir. Ambulans çağırıp 112 hizmetlerinden yararlananların oranı \%39,0'dır. Hizmetten yararlananların \%79,0'ı çağıı merkezi ile iletişimden, $\% 82,9^{\prime} u$ ambulansın ve kullanılan malzemenin temizliğinden, \%82,5'si ambulans ekibinin tutum ve davranışlarından, $\% 74,8$ 'i sorulara verilen anlaşılır yanıtlardan, \%70,9'u hasta hakkında verilen bilgiden, $\% 85,5^{\prime} \mathrm{i}$ hasta mahremiyetine gösterilen özenden ve $\% 82,9^{\prime} \mathrm{u}$ hastaya uygulanan tıbbi müdahaleden memnun olduklarını bildirmişlerdir. 112 çağrı merkezine tıbbi yardım için çağrıda bulunulduğunda grubun \%90,0'ı "olay yerinin adresi", \%86,3'ü "hastanın durumu", \%53,3'ü "olay" hakkında bilgi verileceğini bilmektedir.

Sonuç: Personel tutum ve davranışları, güvenirliği, tıbbi müdahale ilkeleri ve hasta mahremiyetine gösterilen özen, ambulans ekipman donanımı ve temizliğinden memnuniyet oldukça yüksek düzeydedir. 112 çağrı merkezi ile iletişim, hastanın durumu ve sorumlu personel hakkında bilgilendirme, etkin yönlendirme, olay yerine ulaşım süresinin kısaltılması, personel tutum ve davranışlarının iyileştirilmesi yoluyla memnuniyet düzeyi daha da yükseltilebilir.

Anahtar Kelimeler: 112 acil yardım hizmetleri, genel popülasyon, memnuniyet düzeyi

\begin{abstract}
Aim: The satisfaction of patient is the most important quality criteria in health care organization. Determination of patient satisfaction is important for increasing quality of service and for providing more qualified service in accordance with patient's requirement. This study was carried out to determine the level of knowledge, thoughts and satisfaction of the public about the 112 Emergency Health Services.
\end{abstract}

Material and Method: This cross-sectional, self-report study was conducted in May 2013 by applying a face-to-face survey to 600 citizens in 6 regions randomly selected among 18 stations providing emergency health services in Kayseri.

Results: The mean age of the study group was $35.25 \pm 11.38$ and $52.7 \%$ of the group were women, $67.0 \%$ of the group were married and $64.6 \%$ of the participants were trained in high school and above. According to our findings the $94.8 \%$ of the population know the emergency call numbers, $87.2 \%$ of them were calls for medical help for "emergency situations". 39.0\% of the people have called for ambulance. Participants stated that they were very satisfied with contacting to call centre (79\%), with cleanliness of ambulance (82.9\%), with attitudes and behaviours of the team (82.5\%), with the intelligibility of all responses to questions $(74.8 \%$ ), with the given information about the patient $(70.9 \%)$, with care for patients privacy (85.5\%). The majority of population know that the 112-emergency call centre asks for information about "the address of the incident" (90.0\%), "performance status" (86.3\%) and about the "case" (53.3\%)

Conclusion: People are very satisfied with ambulance hygiene and equipment, transportation time, staff's attitude and behaviour, communication, informing, patient confidentiality and medical intervention.

Keywords: 112 emergency health services, general population, satisfaction level 


\section{GíRiş}

Sağlık hizmetlerinin, diğer hizmet ve sektörlerden önemli bazı farklılıkları vardır. Bunlardan birisi sağlık hizmetlerinin ikame edilemez ve ertelenemez özelliğidir. Hasta olan kişinin önerilen tedavi yöntemini başka mal veya hizmetle değiştirme şansı hemen hemen hiç yoktur ya da çok sınırlıdır. Özellikle acil ve akut, kişiye acı veren ve sağlığını tehlikeye atan sağlık hizmetleri talepleri ertelenemez. ${ }^{[1,2]}$ Acil ve akut sağlık hizmetlerinde ilk profesyonel sağlık hizmetlerini, hastane öncesi acil sağlık hizmetleri yerine getirmektedir. Hastane öncesi acil sağlık hizmetleri; afet, kaza ya da hastalık sonucunda acil yardıma ihtiyaç duyan bireylere olay yerinde acil bakım desteği sağlanıp, güvenli bir şekilde hastaneye transport edilmesini kapsayan bir müdahale zinciridir. ${ }^{[3,4]}$ $\mathrm{Bu}$ hizmetlerin esas amacı özellikle büyük travma, kronik hastalık ve ani gelişen sağlık sorunlarına bağlı morbidite ve mortalitenin azaltılmasıdır. ${ }^{[3-5]}$

Türkiye'de hastane öncesi acil sağlık sisteminin temeli 1985 yılında "077-Hızır Acil Servis" hizmeti ile atılmıştır. 1994 yılında "077" kısa kod çağrı numarası yerini "112 Acil Yardım ve Kurtarma" çağrı sistemine bırakmıştır. ${ }^{[6]}$ Türkiye'de 112 acil sağlıkhizmetleri çağrı numarası dışında Yangın İhbar (110), Polis İmdat (155), Jandarma İhbar hattı (156), Sahil Güvenlik (178), AFAD (122) ve Orman Yangın (177) gibi acil hizmet birimlerinin ayrı bir çağrı numarası bulunmaktadır. ${ }^{[7,8]}$ Birden fazla olan acil çağrı numaralarının tek numara altında toplanmasını sağlamak üzere "112 Acil Çağrı Merkezleri Projesi" geliştirilerek, 2005 yılında Antalya ve Isparta pilot uygulama illeri olarak seçilmiş ve 2010 yılında çağrı merkezleri hizmet vermeye başlamıştır. Bugün itibariyle toplam 45 ilde 112 acil çağrı merkezi faaliyete geçmiş bulunmaktadır. ${ }^{[9]}$ Kayseri ilinde Ocak 2019'da 112 acil çağrı merkezi faaliyete geçmiştir. ${ }^{[10]}$ Kalan 36 ilde 112 acil çağrı merkezi sürecine geçiş devam etmekle beraber, süreç tamamlandığında tüm Türkiye'de bütün acil yardım çağrılarına tek numara olarak" 112 " numarasıyla hizmet sağlanacaktır. ${ }^{[11,12]}$ Ayrıca 112 acil çağrı merkezleri sistemiyle birlikte günümüz teknolojisinin getirdiği fırsatlar kullanılarak "e-çağı (e-call)" projesi geliştirilmiştir. Bu proje kapsamında, bazı araba firmalarılyla birlikte yürütülen "e-çağrı (e-call)" sistemiyle; kaza anında 112 acil çağrı merkezinin otomatik olarak aranması yoluyla -kazazede bilinçsiz olsa dahi-, kaza yerinin coğrafi koordinatlarının ve ilgili diğer bilgilerin çağı merkezine iletimi sağlanmaktadır. 112 acil çağı merkezleri sisteminin getirdiği yeniliklerden biri de engelli bireylere yönelik geliştirilen "Engelsiz 112"dir. Engelli bireylerin, 112 acil çağrı merkezi ile iletişime geçmelerine imkân sağlayan telefon/tabletlerine indirebilecekleri bir uygulama geliştirilmiştir. ${ }^{[8,9]}$

Acil sağlık hizmetleri süreci, acil durumlarda yardıma gereksinimi olan bireylerin "112" kısa kod çağrı numarasını (cep telefonu, ankesörlü ve sabit hatlı telefonlardan ücretsiz olarak erişimle) aramasıyla başlar. ${ }^{[11-13]}$ Çağrıyı alan 112 acil çağrı merkezi çalışanı hizmet akışını sağlıklı bir iletişim sayesinde üç adımda gerçekleştirmektedir. Birinci adımda gelen çağrı en fazla 30 saniye içinde alınıp gelen çağrı değerlendirilebilmelidir. ${ }^{[14]}$ Sistemde yaşanan sorunlardan en önemlisi asılsız çağrıların çokluğudur. Kayseri'de 2019 Ekim ayı 112 acil çağrı merkezine toplamda 136950 (\%52'si sağlık çağrıları) çağrı alınmış, bunların \%73'ünü asıısız çağrılar oluşturmuştur. ${ }^{[10]}$ İkinci adımda, 1-3 dakika içerisinde ekiplerin olayın gerçekleştiği yere yönlendirilmesidir. ${ }^{[14]} 2017$ Sağlık Bakanlığı verilerine göre 2 bin 735 acil yardım istasyonu ve 4 bin 910 ambulansı (acil yardım ve kurtarma) ile 5 milyon 465 bin 503 hastaya tahliye ve sağlık hizmeti sağlanmıştır. Yıllar içerisinde azalmakla beraber 2017 yılında 112 acil yardım istasyonu başına düşen nüfus 30867, 112 acil yardım ambulansı

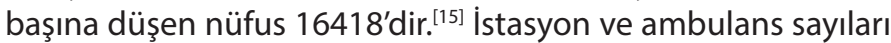
vakalara ulaşma süresini etkilemektedir. İdeal vakalara ulaşma

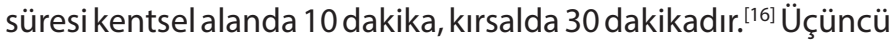
ve son adımda ise, olay yerine yönlendirilen ekipler tarafından vatandaşa verilmesi gereken bakım ve müdahalenin eksiksiz yerine getirilmesidir. ${ }^{[14]}$

Bu çalışma Kayseri ilinde halkın 112 acil yardım hizmetleri hakkında bilgi, düşünce ve memnuniyet düzeylerini değerlendirmek amacıyla yapılmıştır.

\section{GEREÇ VE YÖNTEM}

Kesitsel nitelikli, öz bildirime dayalı bu çalışma 2013 yılı mayıs ayında Kayseri ilinde acil sağlık hizmeti sunan 18 acil yardım istasyonu arasından rastgele seçilen 6 bölgede 600 kişiyle yüz-yüze anket uygulanarak yapılmıştır. Anket formu araştırma grubunun sosyo-demografik özellikleri, 112 acil sağlık hizmetlerinin yapılanması, içeriği ve işleyişi ile ilgili düşüncelerini ve hizmetten memnuniyet düzeyini ölçen 34 soru içermektedir. Çalışma Helsinki prensiplerine uygun olarak planlanmıştır.

Memnuniyet düzeyi "memnun değilim" "memnunum" ve "çok memnunum"; düşünceler "katılıyorum", "katılmıyorum" ve "kararsızım" şeklinde değerlendirilmiştir. Araştırmanın verileri bilgisayar ortamında SPSS 15.0 (Chicago, IL, USA) programı ile değerlendirilmiş, istatistiksel analizde yüzde ve frekans dağılımları, aritmetik ortalama, standart sapma hesaplanarak yapılmıştır.

\section{BULGULAR}

Araştırmaya katılanların yaş ortalaması 35,25 $\pm 11,38, \% 33,7$ 'si (202) 26-35 yaş arasındadır. Katıımcıların \%52,7'i (316) kadın ve $\% 67,0$ 'si (402) evlidir. \%2,0'ı (12) okuma yazma bilmezken $\% 26,8^{\prime i}$ (161) üniversite mezunudur. Katılımcıların \%31,3'ü ev hanımı (188), \%20,5'i işçidir (123) ve katılımcıların tamamının bir sosyal güvencesi bulunurken, \%82,7'si (496) SSK'Iıdır (Tablo 1).

Araştırma grubundakilerin $\% 94,8^{\prime} \mathrm{i}$ acil sağlık hizmetlerinin numarasını bildiklerini, \%88,3'ü doktorun (530), \%69'u hemşirenin (414) ve \%32,8'i şoförün (197) ambulanslarda görev alan çalışanlar olduğunu ve $\% 77,5^{\prime} \mathrm{i}$ hasta/yaralı nakli için 112 acil sağlık hizmetlerinin aranması gerektiğini ifade etmişlerdir. \%90'ı adres (540), \%86,3'ü hastanın durumu (518) ve \%53,3'ü olayın ne olduğunun (320) 112 acil sağlık hizmetleri arandığında söylenmesi gerektiğini ifade 


\begin{tabular}{|c|c|c|}
\hline$(n=600)$ & $\mathbf{n}$ & $\%$ \\
\hline \multicolumn{3}{|l|}{ Yaş } \\
\hline 18 - 25 yaş arası & 135 & 22,5 \\
\hline $26-35$ yaş arası & 202 & 33,7 \\
\hline $36-45$ yaş arası & 157 & 26,2 \\
\hline $46-55$ yaş arası & 69 & 11,5 \\
\hline $56-72$ & 37 & 6,1 \\
\hline \multicolumn{3}{|l|}{ Cinsiyet } \\
\hline Erkek & 284 & 47,3 \\
\hline Kadın & 316 & 52,7 \\
\hline \multicolumn{3}{|l|}{ Medeni Durum } \\
\hline Evli & 402 & 67,0 \\
\hline Bekâr & 158 & 26,3 \\
\hline Eşi Ölmüş/Ayrı & 40 & 6,7 \\
\hline \multicolumn{3}{|l|}{ Eğitim Durumu } \\
\hline Okuryazar değil & 12 & 2,0 \\
\hline Okuryazar & 7 & 1,2 \\
\hline Illköğretim (ilkokul ve ortaokul) & 193 & 32,2 \\
\hline Lise & 227 & 37,8 \\
\hline Üniversite & 161 & 26,8 \\
\hline \multicolumn{3}{|l|}{ Meslek } \\
\hline Ev hanımı & 188 & 31,3 \\
\hline İşçi & 123 & 20,5 \\
\hline Memur & 121 & 20,2 \\
\hline Esnaf & 82 & 13,7 \\
\hline Öğrenci & 41 & 6,8 \\
\hline Emekli & 26 & 4,3 \\
\hline Serbest Meslek & 19 & 3,2 \\
\hline \multicolumn{3}{|l|}{ Sosyal Güvence } \\
\hline SSK & 496 & 82,7 \\
\hline BAĞ-KUR & 56 & 9,3 \\
\hline Emekli Sandığı & 40 & 6,7 \\
\hline Yeşil Kart & 8 & 1,3 \\
\hline
\end{tabular}

etmişlerdir. Ambulansların çağrılara geç gelme nedeni olarak, grubun \%77,2'si trafiğe ait nedenler (yol çalışması, ışıklar, yoğun trafik), \%9,0'ı adresi bulamama ve $\% 6,5^{\prime} i$ personele ait faktörleri göstermişlerdir (Tablo 2).

Araştırma grubundakilerin \%92,1'i ülkemizde 112 ambulans hizmetlerinden kesinlikle ücret alınmadığı, \%89,3'ü ambulansın geç gelme nedeninin trafikteki insan davranışları olduğu, \%89,8'i hastanın hayati tehlikesi olması durumunda müdahale öncesi izin alınmasına gerek olmadığı düşüncelerine katıldıklarını ifade etmişlerdir. \%74,6'sı ambulansların vakaya her zaman geç geldiği ve $\% 39,8$ i ambulansa hasta yakınının alınması yasak olduğu düşüncesine katılmadıklarını ifade etmişlerdir (Tablo 3).

Araştırma grubunun \%79,0'ı 112 acil sağlık hizmetleri çağrı merkezini aradığında iletişimden, $\% 82,9^{\prime} u$ ambulansın ve kullanılan malzemelerin temizliğinden ve hasta/yaralıya yapılan tıbbi müdahaleden memnun olduklarını ifade etmişlerdir. \%29,1'i hasta/yaralısı hakkında verilen bilgiden ve \%25,2'si sorularına ambulans ekibi tarafından anlaşılır cevaplar verilmesinden memnun olmadıklarını ifade etmiştir (Tablo 4).
Tablo 2. Araştırma grubunun acil sağlık hizmetlerinin yapısı, içeriği ve işleyişine yönelik bilgi durumları

\begin{tabular}{|c|c|c|}
\hline$(n=600)$ & $\mathbf{n}$ & $\%$ \\
\hline \multicolumn{3}{|l|}{ Acil sağlık hizmetleri çağrı numarasını bilme } \\
\hline Evet & 569 & 94,8 \\
\hline Hayır & 31 & 5,2 \\
\hline \multicolumn{3}{|l|}{ Ambulansta kimler görev alır? * } \\
\hline Doktor & 530 & 88,3 \\
\hline Hemşire & 414 & 69,0 \\
\hline Şoför & 197 & 32,8 \\
\hline Acil Tıp Teknisyeni (ATT) & 93 & 15,5 \\
\hline Sağlık Memuru & 46 & 7,7 \\
\hline Paramedik & 37 & 6,2 \\
\hline \multicolumn{3}{|l|}{ Hangi durumlarda 112 aranmalı* } \\
\hline Hasta /Yaralı Nakli & 447 & 77,5 \\
\hline Hasta /Yaralı Tedavisi & 400 & 66,7 \\
\hline Doğum & 309 & 51,5 \\
\hline Acil durum & 147 & 24,5 \\
\hline Cenaze Nakli & 124 & 20,7 \\
\hline \multicolumn{3}{|l|}{112 çağrı merkezi aradığında neler söylenmeli * } \\
\hline Adres & 540 & 90,0 \\
\hline Hastanın durumu & 518 & 86,3 \\
\hline Olayın ne olduğu & 320 & 53,3 \\
\hline Hastanın yaşı & 41 & 6,8 \\
\hline Yaralı sayısı & 16 & 2,7 \\
\hline Ad/soyadı & 27 & 4,5 \\
\hline Hastaya ait diğer hastalıklar & 4 & 0,7 \\
\hline Diğer halk sağlığı ekiplerinin aranması & 4 & 0,7 \\
\hline Kimlik bilgisi & 14 & 2,3 \\
\hline Telefon numarası & 3 & 0,5 \\
\hline Olayın meydana geldiği zaman & 3 & 0,5 \\
\hline Çevredeki imkanlar hakkında bilgi & 3 & 0,5 \\
\hline \multicolumn{3}{|l|}{ Ambulansların geç gelme nedeni } \\
\hline Trafik & 463 & 77,2 \\
\hline Adresi bulamama & 54 & 9,0 \\
\hline Personele ait nedenler (umursamama, ciddiyetsizlik vb.) & 39 & 6,5 \\
\hline İş yoğunluğu & 35 & 5,8 \\
\hline Asılsız ihbarlar & 9 & 1,5 \\
\hline \multicolumn{3}{|l|}{ İhtiyacınız olduğunda 112 çağrı merkezi aradığınızda ulaşamama } \\
\hline Evet & 36 & 6,0 \\
\hline Hayır & 564 & 94,0 \\
\hline \multicolumn{3}{|l|}{ Ambulans (112 çağrı merkezi) çağrısında bulunma } \\
\hline Evet & 234 & 39,0 \\
\hline Hayır & 366 & 61,0 \\
\hline \multicolumn{3}{|l|}{ Çağrıyı kim için yaptınız? (n=234) } \\
\hline Kendisi & 13 & 5,6 \\
\hline Yakını & 96 & 41,1 \\
\hline Tanımadığı & 49 & 20,9 \\
\hline Arkadaşı & 49 & 20,9 \\
\hline Komşusu & 27 & 11,5 \\
\hline \multicolumn{3}{|l|}{ Hangi durum için ambulans çağırdınız? $(n=234)$} \\
\hline Acil durum & 204 & 87,2 \\
\hline Devam eden bir hastalık durumunun ağırlaşması & 30 & 12,8 \\
\hline
\end{tabular}




\begin{tabular}{|c|c|c|c|c|c|c|c|c|}
\hline \multirow{2}{*}{$(n=600)$} & \multicolumn{2}{|c|}{ Katılıyorum } & \multicolumn{2}{|c|}{ Katılmıyorum } & \multicolumn{2}{|c|}{ Kararsızım } & \multicolumn{2}{|c|}{ Toplam } \\
\hline & $\mathbf{n}$ & $\%$ & $\mathbf{n}$ & $\%$ & $\mathbf{n}$ & $\%$ & $\mathbf{n}$ & $\%$ \\
\hline Ülkemizde 112 ambulans hizmetlerinden kesinlikle ücret alınmaz & 553 & 92,1 & 25 & 4,2 & 22 & 3,7 & 600 & 100,0 \\
\hline $\begin{array}{l}\text { Ambulans hastayı/yakınını istediği sağlık kuruluşuna götürmek } \\
\text { zorundadır. }\end{array}$ & 412 & 68,7 & 128 & 21,3 & 60 & 10,0 & 600 & 100,0 \\
\hline Ambulans vakaya her zaman geç gelir & 76 & 12,7 & 448 & 74,6 & 76 & 12,7 & 600 & 100,0 \\
\hline Ambulansın geç gelme nedeni trafikteki insanların davranışlarıdır. & 536 & 89,3 & 41 & 6,9 & 23 & 3,8 & 600 & 100,0 \\
\hline $\begin{array}{l}\text { Ambulanslar çoğu zaman gerekmediği durumlarda da siren çalarak } \\
\text { öncelik hakkını suiistimal eder. }\end{array}$ & 269 & 44,8 & 211 & 35,2 & 120 & 20,0 & 600 & 100,0 \\
\hline Ambulansa hasta yakınının alınması yasaktır. & 288 & 48,0 & 239 & 39,8 & 73 & 12,2 & 600 & 100,0 \\
\hline $\begin{array}{l}\text { Hasta yakını şartların uygunluğunda ambulansın ön kabine } \\
\text { alınabilir. }\end{array}$ & 510 & 85,0 & 57 & 9,5 & 33 & 5,5 & 600 & 100,0 \\
\hline $\begin{array}{l}\text { Hastanın hayati tehlikesi olması durumunda müdahale öncesi izin } \\
\text { almasına gerek yoktur. }\end{array}$ & 539 & 89,8 & 45 & 7,5 & 16 & 2,7 & 600 & 100,0 \\
\hline
\end{tabular}

Tablo 4. 112 Ambulans Çağrısı Yapan Kişilerin Acil Sağlık Hizmetleri Çalışanlarının Davranışları Hakkında Memnuniyet Düzeyleri

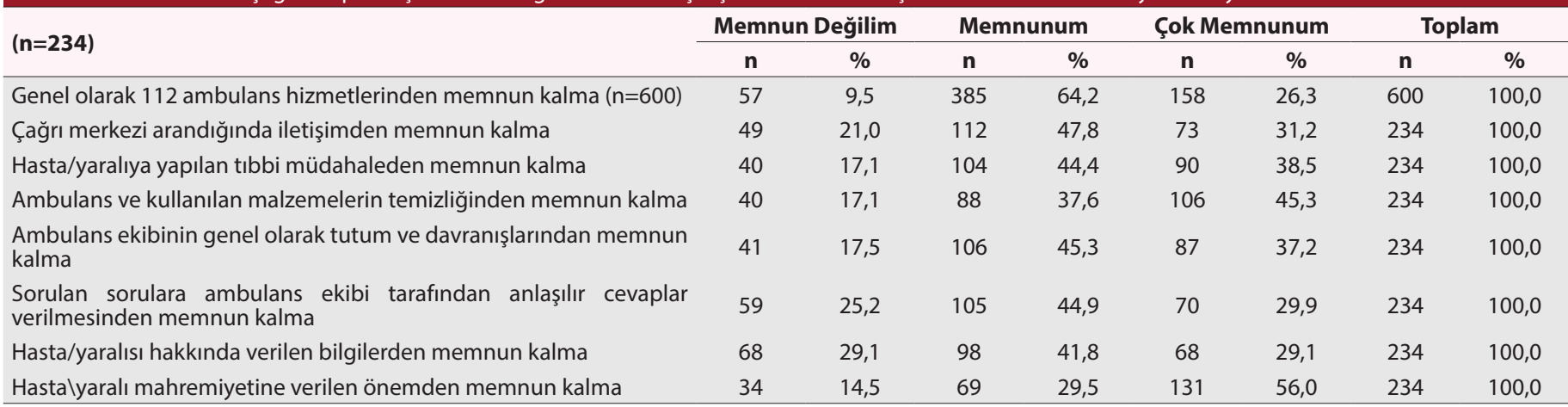

\section{TARTIŞMA}

Acil tıp sistemi (ATS), acil bir olayın bildirilmesinden kesin tedavi uygulanıncaya kadar olay yerinde ve ambulansta acil hasta bakımı sağlayan bir sistemdir. ${ }^{[17]}$ ATS, sağlık sisteminin vitrinidir. Hastane öncesi sağlık hizmetleri, hasta ve yarılıya ilk müdahale edecek profesyonel sağlık birimleri olduğu için, gerek tüketici beklentilerini karşılayan mevcut hizmet kalitesini korumak, gerekse gelişen tıbbi teknolojiler paralelinde hizmetin yeniden yapılandırılması ve sunumuna yönelik iyileştirmelerle daha etkin ve verimli hale getirilmesinde halkın acil sağlık hizmetlerinin yapısı, içeriği, işleyişi ile ilgili bilgi düzeyleri ve aldıkları hizmetten memnuniyetleri temel belirleyici faktörlerdir.

Nitekim çalışmamızda halkın büyük bir çoğunluğu acil sağlık hizmetleri iletişim numarasını, yapısı, işleyişi ve sunucu özelliklerini ve hizmet kullanım endikasyonlarını bilmektedirler. Hizmetin finansal ve fiziksel ulaşılabilirliği, iletişim, hizmet sunumu bilgilendirme basamaklarında olumlu çalışan tutum ve davranışları, hasta mahremiyetine gösterilen özen, ambulans ekipman donanımı ve hijyeni temel memnuniyet parametrelerini oluşturmuştur.

Çalışmamızda düşük düzeyde olmakla birlikte acil sağlık hizmetleri kısa kod çağıı numarası 112'yi bilmeyenler $(\% 5,2)$ bulunmaktadır. Bu durum çalışmanın yapıldığı dönemde acil durum çağrıları için kullanılabilen birden fazla (155-156-158-
110-112-177-122) çağrı numarasının bulunmasına, dolayısıyla kişilerin acil tıbbi yardım çağrı numarasını hatırlayamamasına sebep olmuş olabilir. Ülkemiz genelinde 112 acil yardım ağrı merkezleri yardım numaralarının tek numarada (112'de) birleşmesiyle bu sorunun ortadan kalkacağı; tek numaranın hem halk tarafından kolay hatırlanması hem de halk sağlığı ekipleri (itfaiye-asayiş-sivil savunma vb.) arasında koordinasyon yaratarak acil vakalara eş zamanlı ulaşım ve müdahale etme imkanı sağlayacağı düşünülebilir.

Çalışmamızda 112 acil çağıı merkezini arayıp ulaşamayanların oranı düşük olmakla birlikte, önemli düzeydedir $(\% 6,0)$. Kolay ulaşılabilirlik, erken müdahale, doğru tanı ve tedavi, hızlı nakil etkili bir acil sağlık hizmetinin ana unsurlarıdır. Ülkemizde 112 acil çağrı hizmetlerinde fiziksel ulaşılabilirliği olumsuz etkileyen en önemli faktörlerden birisi asılsız çağrılardır. Nitekim iç işleri bakanlığı verilerine göre, 112 acil çağı merkezlerine, Türkiye genelinde 2019 yılının ilk 7 ayında alınan çağrıların \%66,6'sını asılsız çağrılar oluşturmaktadır. ${ }^{[0]}$

Sonuçta 112 aramalarında asılsız çağrıların çokluğu hem çağıı karşılayan personelin gerçek vakaların ayırımını yapmada zorlanmasına, hem de gerçek vakalar için çağrıda bulunan kişilerin sisteme geç girmesine ya da hiç girememesine neden olabilmektedir.

112 acil hizmetlerine hızlı müdahale gerektiren acil vakaların başvurması beklenirken başvuruların yaklaşık \%40'ının 
acil olmayan olgular nedeniyle yapıldığı saptanmıştır. ${ }^{[21]}$ Diğer taraftan araştırma grubunun üçte ikisinin hasta/yaralı nakli ve beşte birinin cenaze nakli için 112 çağrı sisteminin aranabileceğini ifade etmeleri düşündürücüdür. Bu durum 112 acil sağlık hizmetlerinin 7/24 esasına dayalı ve ücretsiz hizmet vermesine bağlı gelişebileceği gibi, geçmişte yanlış yapılanan "acil hizmetlerin yalnızca nakil hizmeti yürütür"yerleşik algının bir kalıntısı olarak da düşünülebilir.

BilindiğigibiTürkiye'de, hastaneöncesiacil sağlıkhizmetlerinde "kap ve götür" prensibine dayalı Anglo-Amerikan modeli uygulamaktadır. ${ }^{[19]}$ Alanda başlanan hayat kurtarıcı tıbbi tedavi ve bakım, nakil sırasında devam ettirilerek hasta ileri acil bakım için hastane acil servislerine ulaştırılmaktadır. 112 acil yardım çağrısı alındığında, çağrı karşılayan personel asılsız vakaları eleyerek, olay yerine en yakın ve uygun ambulans ekibini yönlendirerek hizmeti aktive etmektedir. ${ }^{[20]} 112 \mathrm{ASH}$ öncelikle travma (trafik kazası, darp, yüksekten düşme vb.) gibi akut gelişen olaylar ile mevcut bir kronik hastalık (DM, HT vb.) sonucu medikal durumu değişen hastaları olay yerinde ve ambulansta gerekli müdahaleleri uygulayarak hastaneye transport etmeye dayalı sağlık hizmeti sunmaktadır.

Çalışmamızda araştırma grubunun büyük çoğunluğu tarafından 112 çağrı merkezi arandığında olay yerinin adresi $(\% 90,0)$, hastanın durumu $(\% 86,3)$ ve olayın ne olduğu $(\% 53,3)$ hakkında çağrı karşılayıcıya bilgi verilmesi gerektiği ifade edilmiştir. Keza acil sağlık hizmetleri gereksinimi duyduktan sonra sadece acil sağlık hizmetlerini numarasını (112) aramak etkin hizmet sürecinin doğru yapılanması için yeterli değildir. Çağrıyla birlikte 112 Komuta Kontrol Merkezine, biliniyorsa olayın gerçekleştiği yerin tam adresi, yoksa bilinen yakın merkezlere (okul, market, cami vb.) konumlarını, olayın ne olduğu (trafik kazası mı? zehirlenme mi?), hasta sayısı (birden fazla ambulans gereksinimi var mı?), hastanın durumu (bilinci açık mı?) gibi önemli bilgiler mutlaka iletilmelidir. Ayrıca telefon numarası, ad soyadı, çağrıda bulunan kişinin ilkyardım bilgisinin olup olmadığı gibi bilgilerde söylenmelidir. Nitekim doğru ifade edilecek bilgiler ambulansın olay yerine doğru ve hızlı yönlenmesini sağlayacak, olay yerine ulaşım süresi kısalacak, hastaya uygun-erken müdahale edilmesini sağlayacaktır.

Sağlık hizmetleri kalitesinin değerlendirilmesinde hasta memnuniyeti önemli bir göstergedir. ${ }^{[22]} 112$ acil çağrı merkezi hizmetlerinin kaliteli bir biçimde sunulması ve hasta beklentileri doğrultusunda sürekli iyileştirilmesi, hedef kitle ile etkin iletişim kurulması ve hedef kitle memnuniyetinin artması açısından oldukça önemlidir. Acil duruma hızlı yardımın ulaştırılması hedef kitlenin memnuniyet ve sadakat düzeyinin artmasına katkıda bulunmaktadır. ${ }^{[14]}$ Çalışma bulgularımız ile örtüşür şekilde Çanakkale'de yapılan bir çalışmada hastane öncesi acil sağlık hizmetleri çağrı numarasına hızlı bir şekilde ulaşılması ve çağrı karşılayıcı personelin etkin iletişim becerisi hasta ve hasta memnuniyetini en fazla arttıran faktörler olarak rapor edilmiştir. ${ }^{[23]}$

\section{SONUÇ}

Halkın yarıdan fazlası 112 acil sağlık hizmetlerinden memnundur. Personelin tutum ve davranışları, güvenirliği, tıbbi müdahale ve hasta mahremiyetine gösterilen özen, ambulansın ekipman donanımı ve temizliğinden memnuniyet oldukça yüksek düzeydedir. Her 5 kişiden biri cenaze nakli vb. amaç dışı kullanımlar için ambulans çağrılması gerektiğini düşünmektedir. Halkın büyük çoğunluğu hasta yakınlarının ambulansa alınmamasına yönelik yasağa tepkilidirler. 112 çağrı merkezi ile iletişim, hastanın durumu ve sorumlu personel hakkında bilgilendirme, etkin yönlendirme, ambulansın olay yerine en kısa sürede ulaşımının sağlanması, personel tutum ve davranışlarının iyileştirilmesi yoluyla memnuniyet düzeyi daha da yükseltilebilir.

\section{ETIKK BEYANLAR}

Etik Kurul Onayı: Bu araştırmada 2020 öncesi (2013 yılı) verileri kullanılmış ve araştırma 2020 öncesinde sonuçlandırılmıştır. 3 Kasım 2015 tarih 28617 sayılı Resmi Gazete'de yayımlanan Klinik Araştırmalar Yönetmeliğine göre etik kurul onayı alınmamıştır. "Bu Yönetmelik, ruhsatlı veya izinli olsa dahi insanlar üzerinde yapılacak biyoyararlanım ve biyoeşdeğerlik çalışmaları, ilaçlar, tıbbi ve biyolojik ürünleri içerir. (madde 2- (1))" maddesi uyarınca elde edilmiştir. Dolayısıyla klinik anket çalışmaları yönetmelik kapsamı dışındadır. Bu çalışma, Kişisel Verilerin Korunması Kanunu'na uygun olarak, hasta verilerinin anonim hale getirilmesi ve Helsinki Deklarasyonu'nun 2013 Brezilya revizyonu ve İyi Klinik Uygulamalar kılavuzuna uygun olarak hazırlanmıştır.

Hakem Değerlendirme Süreci: Harici çift kör hakem değerlendirmesi.

Çıkar Çatışması Durumu: Yazarlar bu çalışmada herhangi bir çıkara dayalı ilişki olmadığını beyan etmişlerdir.

Finansal Destek: Yazarlar bu çalışmada finansal destek almadıklarını beyan etmişlerdir.

Yazar Katkıları: Yazarların tümü; makalenin tasarımına, yürütülmesine, analizine katıldığını ve son sürümünü onayladıklarını beyan etmişlerdir.

\section{KAYNAKLAR}

1. Odabaşı Y. Sağlık hizmetleri Planlaması. 9. Baskı. Eskişehir: Anadolu Üniversitesi Yayınları, 2001.

2. Tengilimoğlu D, Akbolat M, Işık O. Sağlık İşletmelerinde Yönetim. Ankara: Nobel Yayıncılık, 2015.

3. Ekşi A. Kitlesel Olaylarda Hastane Öncesi Acil Sağlık Hizmetleri Yönetimi. İzmir: Kitapana Yayınevi, 2016.

4. Şişman A. Şişman Y. Terzi Ö. Samsun 112 acil çağrılarının ve acil sağlık hizmet istasyonlarının konumlarının CBS ile değerlendirilmesi. III. uzaktan algılama ve coğrafi bilgi sistemleri sempozyumu, 11 - 13 Ekim 2010, Gebze - KOCAELI, 523-532. http://uzalcbs.org/wp-content/ uploads/2016/11/2010_64.pdf

5. Bélanger V. Ruiz A. Soriano P. Recent advances in emergency medical services management. faculté des sciences de l'administration. Quebec, Canada: Université Laval, 2015. https://www.cirrelt.ca/DocumentsTravail/ CIRRELT-2015-28.pdf 
6. Erbay H. Türkiye'de hastane öncesi acil sağlık hizmetlerinin numarası niçin 112 ? ambulans hizmetleri bağlamında bir yakın tarih araştırması. Lokman Hekim Derg 2017;7(1):28-32.

7. http://www.antalya.gov.tr/112-acil-cagri-merkezi (Erişim Tarihi: 11.11.2019)

8. Sönmez M. Kamuda teknoloji kullanımı, avrupalılaşma, etkinlik ve verimlilik açısından tek numara (112) acil çağrı merkezleri projesi ve e-çağrı (e-call) uygulamaları. Türk İdare Derg 482:149-82.

9. https://www.icisleri.gov.tr/bilgiislem/yeni-nesil-112-acil-cagri-merkezi (Erişim Tarihi: 11.11.2019)

10. http://www.kayseri112.gov.tr/112-acil-cagri-merkezi-2019-ekim-ayiistatistikleri (Erişim Tarihi: 11.11.2019)

11. Ekşi A, Yıldırım GÖ. Avrupa Birliği uyum sürecinde tek numara acil çağıı sistemi uygulamasına ambulans personelinin bakışı. The Journal of International Social Research, 7(31): 779-785.

12. http://www.112.gov.tr/112-acm-projesi (Erişim Tarihi: 11.11.2019)

13. Günay N, Yıldırım C. Hastane öncesi bakım (prehospital care). Türkiye Klinikleri J Sur Med Sci 2007;3(1):19-22.

14. Biçer S, Kızmaz S. Antalya 112 acil çağıı merkezi personellerinin hedef kitle ile iletişim sürecinde yaşadıkları problemler: nitel bir araştırma. Atatürk Illetişim Derg 2017;14:231-60.

15. Sağlık Bakanlığı, Sağlık İstatistikleri Yıllığı 2017, Sağlık Bilgi Sistemleri Genel Müdürlüğü, Ankara 2018. https://dosyasb.saglik.gov.tr/ Eklenti/31096,turkcesiydijiv1pdf.pdf?0 (Erişim Tarihi: 11.11.2019)

16. Yılmaz Karakuş B, Çevik E, Doğan H, Sam M, Kutur A. Metropolde 112 acil sağlık hizmeti. İst Tıp Fak Derg 2014;77(3):37-40.

17. Lilja GP, Swor RA. Emergency medical services. In Tintinalli JE, Kelen GD, Stapczynski SJ. Emergency Medicine A Comprehensive Study Guide 5th ed. New York: McGraw\&Hill 1999; 1-6.

18. Sampson R. Misuse and Abuse of 911. U.S. Department of Justice Office of Community Oriented Policing Services. Problem-Oriented Guides for Police Problem-Specific Guides Series No. 19 Available from: URL:https:// www.cops.usdoj.gov/

19. Paksoy VM. Acil sağlık hizmetlerinde uluslararası uygulama modellerinin karşılaştırması: Anglo-Amerikan ve Franko-German modeli. İnönü Üniversitesi Sağlık Hizmetleri Meslek Yüksekokulu Derg 2016;4(1):6-24.

20. Ambulanslar ve Acil Sağlık Araçları ile Ambulans Hizmetleri Yönetmeliği (2006) http://www.mevzuat.gov.tr/Metin.Aspx?MevzuatKo$\mathrm{d}=7.5 .10834 \&$ Mevzuatlliski=0\&sourceXmISearch=ambulans (Erişim Tarihi: 11.11.2019)

21. Yaylacı S, Cimili Öztürk T, Çelik Yılmazer S. Acil servise ambulansla başvuran hastaların aciliyetinin retrospektif değerlendirilmesi. Acıbadem Üniversitesi Sağlık Bilimleri Derg 2013;4:64-7.

22. Şensoy N, Özmen A, Doğan N, Ercan A, Karabekir HS. Afyonkarahisar II Merkezinde birinci basamak sağlık hizmetlerinde hasta memnuniyeti araştırması. J Clin Anal Med 2014;5(1): 29-34.

23. Uysal I, Temel K, Sevinç Postacı E, Kabaş KŞ. Hastane öncesi acil sağlık hizmetleri sunumunda hasta ve hasta yakını memnuniyetinin değerlendirilmesi. Hastane Öncesi Derg 2019;4(1):1-11. 